\section{Florey's creative power}

\section{E.P. Abraham}

Howard Florey: The Making of a Great Scientist. By Gwyn Macfarlane. Pp.396. (Oxford University Press: Oxford and New York, 1979.) $£ 7.95$.

THIS book is an authoritative biography of Lord Florey in his early and middle life. It is a tribute to a man who had a central role in the story of penicillin and became one of the great figures in the history of medical science. It is also a product of the persistence of Gwyn Macfarlane, who was told by publishers that an unknown.author could not expect to see his biography of a scientist in print unless his subject was already famous in the public mind; and that although Fleming was a household name, Florey was not. Why this was so and how a myth was created are finally discussed in detail. A major theme of the book, however, as its sub-title implies, is the development of Howard Florey as a scientist and the factors that contributed to his success. "To be a great scientist", the author states, "one must (among other things) be a pioneer, a discoverer, a dedicated research worker, and one must be successful"'; and he sets out to show how Florey came to fall within this definition.

In his assessment of Florey's character the author, unlike earlier biographers, has quoted from letters that Florey wrote from England and America to Ethel Hayter Reed, a fellow medical student in Adelaide, with whom he thought he had fallen in love. They were referred to later by Ethel as love letters, but eros scarcely appears in them although agape is sometimes seen. Some of the extracts from this correspondence, between two young people who were fourteen thousand miles apart, seem strangely cautious and business-like. But even those who know the outcome may have a sense of drama and begin to wonder whether marriage will eventually result or not, as problems, difficulties and requirements are laid on the table.

In the event, they married on 19 October 1926 in London a few weeks after Ethel's arrival from Adelaide. The marriage began badly and it was immediately evident that they were unlikely to be perfect partners. She was an attractive woman with intelligence and charm who could write to him on the boat "Do you realise that I shall arrive in England on your birthday: I shall wrap myself up in tissue paper tied with pink ribbon ... . will you accept the present or throw it into the sea?". Yet she was strong willed and difficult to live with and she had written of marriage as an ordeal. He, like many other young men, had ambition, impatience, idealism and private worries about his capability. They were both unduly concerned by thoughts of a lack of money and, with her, fear of poverty seemed to become almost an obsession. Neither had formed positive views of the nature of their relationship. While he had disclaimed any wish to impede her professional life or press her into domesticity, he had also written: "Married women messing about in labs always appear to be slightly pathological to me".

The marriage was not devoid of affection and there were intervals of contentment which coincided with the birth of two children. But it is clear that he did not find in her the ideal companion of his imagination and that some of her own premarital forebodings became realities. $\mathrm{He}$ was exasperated by her increasing deafness; yet other marriages have been happy in the face of greater impediments and the reader is left to wonder whether deeper problems were unresolved.

No general principles to guide the young who aspire to become great scientists are likely to emerge from this topic in the letters, for creative power seems to have been unleashed in some men and stifled in others by emotional frustration. There can be no doubt that Florey's epistolatory attachment to Ethel gave him great comfort during his early years in England, when feelings of loneliness sometimes became acute, and that it removed temptation to indulge in diversions which could have interfered with his great enthusiasm for research. But the relevance of his subsequent dissappointment to his great achievements is a matter for speculation a process of which Florey himself was not much enamoured.

The Florey letters, however, also provide a diary of his early years in Oxford, where he obtained a first class in the Honour School of Physiology, and then in Cambridge, America and London. They describe the experiments he had done and intended to do with laboratory animals on the capillaries, the lymphatics, the omentum and mucus secretion. They tell of his emotional response to music and to the architectural achievements of past centuries and give the critical views of a young Australian on the English society of the day. They contain accounts of his meetings with a number of the great or then powerful figures in preclinical medicine, including Charles Sherrington, A.R. Dean, Edward Mellanby and J.B.S. Haldane. And they show that Florey's poor view of the intellectual content of much clinical teaching and of the quality of clinical research had been formed by the time he had qualified in medicine at Adelaide. All this Gwyn Macfarlane brings together in an admirable manner.

It was Sherrington who suggested to Florey that the time had come for an approach to pathology by a physiologist Sherrington, Dean and later Mellanby were much impressed by his ability and energy in research and their support helped him to obtain positions at Cambridge and the London Hospital and then Chairs at Sheffield and Oxford. The Professorial appointments were made in the face of powerful opposition, for Florey was not regarded as a pathologist by the morbid anatomists who dominated the profession; Macfarlane tells the well-authenticated story of Mellanby arriving late at a crucial meeting of the electoral board in Oxford to find that it had already been decided to offer the chair to another candidate and of his ability to persuade his colleagues to change their decision. He goes on to describe Florey's frustration during his early years in the Sir William Dunn School of Pathology, his fight for what would now seem to be trivial sums of money for research and his disappointment at finding that the great Nuffield benefaction of 1936 would provide a rich endowment for clinical medicine in Oxford, but do nothing for the pre-clinical departments. But Florey rapidly invigorated what was a nearly moribund Department. He continued his work on mucus secretion and on lymph flow and the function of the lymphatic system. A later outcome of his interest in lymph, when labelling with radioisotopes and other new techniques had become available, was the important discovery by J.L. Gowans of the circulation of the lymphocyte.

Florey's work in these fields, often requiring surgery of great skill and designed to obtain unambiguous answers to straightforward questions, virtually established the subject of experimental pathology in this country. This was one of his great achievements.

The book describes how the research on mucus secretion, which originated from anxiety about his own dyspepsia, led indirectly to penicillin. While still at Cambridge, Florey had become interested in Fleming's lysozyme, probably because the presence of this bacteriolytic enzyme in intestinal mucus raised the question whether lysozyme, or a related antibacterial enzyme, was responsible for the protective action of the mucus. His wish to have lysozyme purified seems to have prompted the thought that experimental pathology would benefit from a collaboration of pathologists with chemists or biochemists. But it was only after he became Professor of Pathology in Oxford that he succeeded in obtaining the funds for a biochemist to work in his Department. It was thus that Ernst Chain, a Jewish refugee from Hitler's Germany who had just finished his $\mathrm{PhD}$ at Cambridge and was warmly recommended by Gowland Hopkins, came to the Sir William Dunn School of Pathology in 1935. He worked at first on the mode of action of snake venoms and then, at Florey's suggestion, he turned his attention, with L.A. Epstein, to the mode 


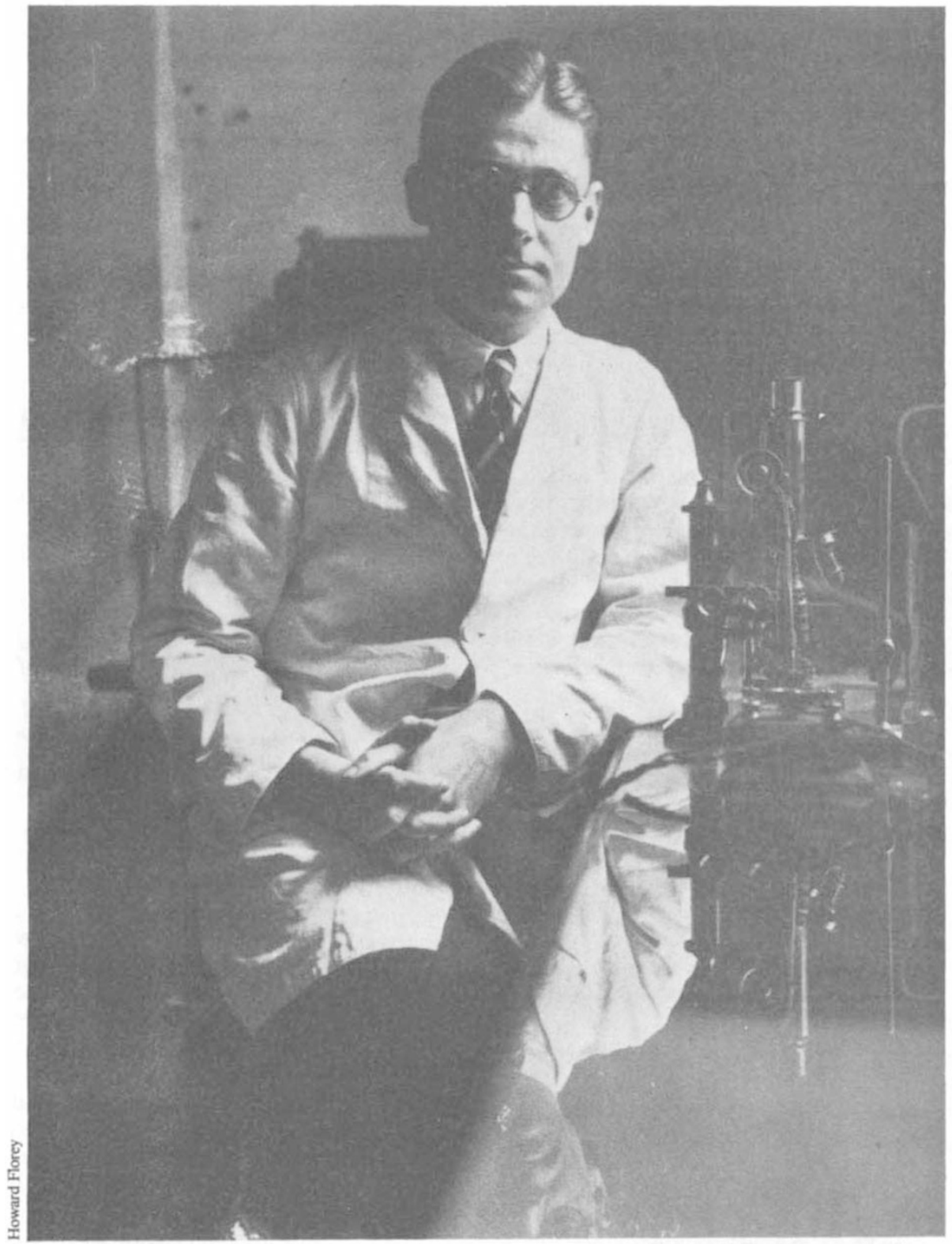

of action of lysozyme.

It has never been possible to write a history of penicillin that would have satisfied all of those who were closely concerned. But in most of its essential features Gwyn Macfarlane's well documented version probably comes as near to the truth as anyone is now likely to get, and it is only his treatment of some of the chemical studies which is open to question. He devotes one chapter to Alexander Fleming and the extraordinary conjunction of chance events (analysed by Ronald Hare in The Birth of Penicillin; George Allen and Unwin: London, 1970) that made it possible for him to discover penicillin in 1928. Why Fleming made no attempt to test its ability to cure bacterial infections in mice, as he could have done, is a question to which he never gave a satisfactory answer. There is no evidence for the suggestion of André Maurois, his biographer, that he was actively discouraged by his chief, Almroth Wright. His claim that he lacked chemical help is unconvincing, because he showed little interest in the work of two young assistants, Ridley and Craddock, who prepared crude extracts of penicillin, and none at all in the later and soon abandoned attempt at isolation by Raistrick, Clutterbuck and Lovell. It seems that the idea of using penicillin as a systemic chemotherapeutic agent simply did not occur to him, nor did it occur to such influential figures as Wright and Topley But Gwyn Macfarlane rightly says "Fleming should not be criticised for what he did not do" and concludes that his genius for discovery was not accompanied by the sort of character needed to exploit what he found.

Ten years after Fleming's discovery, an investigation of penicillin was begun in the Sir William Dunn School of Pathology, as Chain's work on the substrate of lysozyme led him to make a survey of the older literature on bacteriolytic substances. "Dr Chain and I", wrote Florey, "had many discussions on the possible interest of a systematic and thorough study of the known natural antibacterial substances"; and later he said: "eventually he proposed, and I agreed to go along with it, that we should make a thorough investigation of antibacterial substances. This is why we looked at penicillin'. Chain's biochemical interest in penicillin was aroused by its reported instability and Florey was struck by its activity against the staphylococcus, against which the sulphonamides had proved relatively ineffective. However, penicillin was only one of three substances first chosen for study and was at first given no particular prominence. Gwyn Macfarlane leans towards the view that thoughts of "suffering humanity" lay behind the decision to work on penicillin. Florey, however, has stated categorically that this was not the mainspring of the motivation, which was scientific interest, and he did not fail to acknowledge the role of chance: "We happened to hit on an antibiotic which worked in man. We could have worked with hundreds of others and they would have been chemical curiosities".

Florey always maintained that the success of the penicillin project itself, which seemed at the time to be almost miraculous, was due to the combined work of a small group: "I am quite clear that nothing would have gone along except for a group of five or six people". Gwyn Macfarlane gives handsome bouquets to all those concerned in a detailed account of the extraction of penicillin and the dramatic results obtained from well-planned experiments by Florey, first in mice and then in man. But he rightly concludes that it was only Florey's drive and personality that held the group together, and enabled difficulties to be overcome which at first seemed insurmountable in war-time Britain.

Chain made no secret of his view that he had received too little credit and reward for his part in the penicillin story and that the Medical Research Council was guilty of a major error of judgement in not obtaining patent protection for the Oxford work on penicillin. But although it is now widely accepted that a policy which excludes the products of academic medical research from patent cover is a form of idealism that the country cannot afford, this was not so before and during the War. At Florey's suggestion, Chain went to Edward Mellanby, then Secretary of the Medical Research Council. However, Mellanby, who seems to have regarded him as an alien and troublesome personality, was unmoved.The official attitude became the subject of public criticism, but this may have been irrelevant, at least in relation to the achievements in Oxford, because it is by no means certain that a rewarding patent could then have been obtained. Although the results with penicillin were new and farreaching, penicillin itself was not new and it had not been characterised chemically. The methods used in its production were soon to be superseded by others in America. The most important unpublished step in its 
purification (extraction as a salt into water from an organic solvent), which was suggested in Oxford by N.G. Heatley, had already been taken (unknown to him) in 1934 by Lewis Holt, a chemist at St Mary's Hospital whose work was never mentioned by Fleming. Moreover, the penicillin produced later in the United States for clinical use (benzylpenicillin) differed in its side-chain from the penicillin then being studied in Oxford.

The book also contains comments on another aspect of this question. After the clinical trials at Oxford in 1941 Florey decided that American help would be essential for the war-time production of penicillin in quantity. With the agreement of the Medical Research Council and financial support of the Rockefeller Foundation, he and Heatley went to the United States to try to interest the American pharmaceutical industry. Penicillin, then only produced in minute quantities, was far from easy to sell, but Heatley was invited to the Fermentation Division of the Northern Regional Research Laboratory in Peoria to help get a project started. He worked with A.J. Moyer, described in the book as "a fervent anti-British isolationist" with a "positive flair for making moulds do what was wanted". Moyer and Heatley had agreed on a joint publication, but the paper which eventually appeared was in Moyer's name alone. During this time the outlook for penicillin production was revolutionised by the American decision to add corn-steep liquor to the growth medium and to use deep fermentation, and these advances became the subject of American patents. British firms were understandably irked when they discovered that they were required to pay royalties to America to produce a substance that was essentially a British discovery. But equity and patent law may sometimes diverge. At the root of the problem was the fact that the official pre-War world in Britain was entirely unprepared for a situation of the kind that penicillin threw up. And there is, of course, another side to the matter. Without American help it is inconceivable that enough penicillin would have been produced, as it was, to treat all serious battle casualties, British and American, when D-day came in Europe.

The penultimate chapter of the book is headed "Palmam qui meruit ferat", a phrase used by Almroth Wright in a letter to The Times on 31 August 1942 firmly placing a laurel wreath on Fleming's brow. The nature of the publicity that followed can be attributed partly to Florey's refusal to talk to the press, partly to the welcome given to the press by Fleming and others at St Mary's Hospital and partly to the unwillingness or inability of popular writers to acquaint themselves with the facts in the scientific literature. One of these stories, written by a bacteriologist at St Mary's and more ludicrous than others only in the extent of its fabrication, attributed virtually all that had been done in Oxford to Fleming himself. The source of this myth is uncertain, but Gwyn Macfarlane remarks that behind Fleming were Almroth Wright "intensely ambitious for his department" and Lord Moran, Dean of St Mary's Hospital Medical School "Whose dearest wish was for its honour, glory, and financial security" and suspects that an efficient Public Relations Officer was active somewhere in the organisation. Fleming himself is said to have derived an impish glee from the more bizarre stories as he collected cuttings, a reaction that might have been understandable had he not been gaining worldwide gratitude from their publication.

Florey complained of this situation to Edward Mellanby who replied that it was ephemeral and of little consequence and that "in time even the public will realise that in the development of this story of penicillin, the thing that has mattered most has been the persistent and highly meritorious work of your laboratory". There is now now reason to think that the

\section{Olduvai record}

\section{J. Desmond Clark}

Olduvai Gorge: My Search for Early Man. By Mary Leakey. Pp. 181. (Collins: London, 1979.) £6.50.

EAST AFRICA remains unsurpassed in the wealth of discoveries and the understanding these provide about the biological and cultural evolution of our own species. It is no exaggeration to say that the very impressive record of hominid fossils and cultural remains in their palaeoenvironmental setting that has come from East Africa and the Horn over the past twenty years, has revolutionised our knowledge of human phylogeny. The hundreds of fossil hominid remains recovered, often remarkably complete and well preserved, and the circumstances of their preservation have made it possible to identify some of the behavioural adaptations that underlie the beginnings of tool-making and the ensuing intellectual development manifest in the increasing complexity of the tool-kits and the economic strategies that gave rise to them.

A very great deal of what is known today results from the lifetime devoted by Louis and Mary Leakey to their search for early man - a search which has completely vindicated Louis' claim, first made when he was an undergraduate at Cambridge in the $1920 \mathrm{~s}$, that a wealth of evidence awaited discovery in the deep sedimentary sequences of the Great Rift Valley. It was really the first full season's work in 1935 at the Olduvai Gorge in northern Tanzania, which was also Mary Leakey's publicity has ever affected the judgement of scientific bodies of any consequence, but its effect on the public has been far from ephemeral.

Gwyn Macfarlane finally summarises some of the qualities which combined to make Florey an outstanding figure: his great energy and enthusiasm for research; his skill as an experimenter and commitment to experiments that gave clearcut results; his judgement and sense of direction; and his complete intellectual integrity, never clouded by vanity. His colleagues who came to like and admire him will remember that behind a deep reserve there were kindness and consideration for their welfare. It is to be hoped that this well documented book will make his qualities and great contributions to science and medicine more widely known.

E.P Abraham is Professor of Chemical Pathology in the Sir William Dunn School of Pathology at the University of Oxford, UK.

introduction to fieldwork in the African Quaternary, that was the first demonstration of the correctness of Louis' conviction. It was also the first manifestation of his shrewdness - some would say his luck - in having concentrated on the Rift which, as can now be seen, is probably the most significant region in the world for preservation of the Plio-Pleistocene record that spans the emergence and early development of man the tool-maker.

The fossil, geological and cultural evidence is unique, both in its completeness and in the relatively minor disturbance that it has suffered. This has made it possible to reconstruct the changing climatic and ecological conditions under which hominid evolution took place, to find and excavate the activity places of the hominids, and to date all these events. In the 1930 s, there was no way of knowing how old the then earliest fossils and stone tools were. At that time Keith's 'guesstimate' of 200,000 to 400,000 years did not seem unreasonable to many and, indeed, most people then thought in terms of half a million or so years for the beginning of the Pleistocene. Now, K/Ar, uranium fission-track dating and the palaeomagnetic reversal chronology show that the earliest stone tools are about 2 million years old; that the earliest, well-known hominid (Australopithecus afarensis) is between 3 and 4 million years old; and that even earlier, but fragmentary, remains are present in the East African sedimentary record. From the 1960 s onwards, a number of interdisciplinary and international teams have been working in the East African and Ethiopian sections of the Rift and on the adjacent parts of the plateau for example, at Laetoli, Olduvai, Omo, East Turkana, Hadar, and on the 